\title{
BEHAVIOR OF Ceratophora tennentii GUNTHER, 1834 IN RELATION TO AMBIENT TEMPERATURE IN A SELECTED HABITAT IN KNUCKLES FOREST RANGE OF SRI LANKA
}

\author{
P.R.K. Rodrigo', U.K.G.K. Padmalal', I.U.P. Samaraweera' \& J. U. L.D. ayantha 2 \\ ${ }^{1}$ Faculty of Natural Science, Tize Open University of Sri Lanka \\ 2Faculty of Veterinary Nedicine and Animal Science, \\ University cf Peradeniya
}

\begin{abstract}
A research was conducted in the eastern slope of the northern flank of the Knuckles forest range for a period of 3 months from March - June 2002 with the objective of studying the general behavior of $\mathrm{C}$. tennentii related to the ambient temperature. Data was collected for a period of 10 days between 0800 to 1800 hrs using focal sampling method. Juvenilc (J), male $(\mathrm{M})$ and female $(\mathrm{F})$ lizards were otserved and the ambient temperature of the substrate used in the habitat was recordcd. An average temperature in the study sitc fluctuated from $16.80^{\circ} \mathrm{C}$ in the morning, $24.25^{\circ} \mathrm{C}$ at noon and $16.25^{\circ} \mathrm{C}$ in the evening. Activity of all lizards was high around noon (1100-1300 hrs) and it was observed that they are relatively inactive in the morning and evening when the ambient temperatures were minimum. All the groups spent more time on resting $(\mathrm{J}=50.83 \%, \mathrm{M}=42 \%$ and $\mathrm{F}=$ $55.83 \%)$. The most preferred substrates were tree trunks and cardamom plants $(\mathrm{J}=34.3 \%$, $33.5 \%, \mathrm{M}=37.3 \%, 28.2 \%, \mathrm{~F}=13.5 \%, 32.2 \%$ respectively). It can be concluded that the general behavior of $\mathrm{C}$. tennentii correlates with the ambient temperature where a high degree of activity was observed during the daytime. The optimum range could be $20^{\circ} \mathrm{C}$ $24^{\circ} \mathrm{C}$ for captive management of these lixards. They preferred substrates exposed to sunlight such as tree trunks and cardamom plants where there were numerous insects during the flowering season.
\end{abstract}

Proceedings of the Eighth Annual Forestry and : Invironment Symposium 2002 of the Department of Forestry and Environmental Science, Lriversity of Sri Jayewardenepura, Sri Lanka 